\title{
Thematic Learning - Integrative on Cross Curriculum in Social Studies and Language Learning in Elementary Schools on Higher Grade
}

\author{
Ferril Irham Muzaki \\ Universitas Negeri Malang \\ ferril.irham.FIP@UM.AC.ID
}

\begin{abstract}
The purpose of this research are 1) to install the concept of thematic learning in Language teaching; 2). To integrate learning concept of Language with subjects with Social Studies subject; to integrate between social science teaching materials and Indonesian language learning in elementary school. The research method used in this research is a classroom action research consisting of two cycles, the first cycle focuses on the understanding of thematic learning through interactive media, and in the second cycle focuses on understanding the improvement of understanding through the play approach. The result of this research is (1) there is an increase of understanding of thematic concept in flood prevention, (2) there is an increase of knowledge about the use and selection of diction for scientific activity at elementary level and (3) there is increasing comprehension of integrated concept between learning process and process scholarship that occurs in the classroom. Based on the above results it can be concluded that the thematic learning in elementary school in the Language teaching field even though developing the concept of learning across the curriculum. It is suggested to the beneficiaries to use the concept of language learning across the curriculum in learning Indonesian in elementary school.
\end{abstract}

Keywords- Language Learning, Cross Curriculum, Thematic Review

\section{INTRODUCTION}

Cheng, et al (2013: 137) which is expected in thematic learning in higher class is a the-matic lesson with simple language which is translated into concrete sentences. By translating into congruent sentences learners are expected to be able to understand the instructions contained in the book. Learners are found with a variety of backgrounds from economic points of view, distance from home to school, and parent profession.

From the point of view of the economic condition of learners there is a learner who grew up in an orphanage. Students whose condition is orphaned grew up in an orphanage as a worker abroad. The distance from the orphanage to his school was two miles, he took it within thirty minutes. From the point of view from home to school, there is a learner who lives on the edge of the river.
Students are due to economic limitations in the morning after dawn must look for Fish in the river. At six-thirty in the morning, the learner takes the typical market for food to several stores.

From the background of the parent's profession there is a protégé whose father works as a city transport driver. The mother of the students works as a laundry worker in one of the laundry services. The child every morning also helps dry clothes, while one of his colleagues tells his brother works as a public bus. If viewed from the scientific point of view Curriculum 2013 textbook has been designed in accordance with the psychology of child development. Textbooks need to be translated because learners have a background heterogeneity. This textbooks are simple in accordance with the background understanding of learners.

Cheng, et al(2013:137) argues Science textbook inelementary school although designed to follow the pattern set by the Ministry of Education and Culture that is thematic. Learners are introduced to the theme that is discussed from the perspective of Math-ematics, science, Social science, Indonesian language and civics education. The thematic lessons raised are Floods, in teaching the flood of learners invited to see the flood from the point of view of Math-ematics, science, Social science and civics education and des-cribed in Indonesia.

From a mathematical perspective view of learning in understanding Flood is directed at describing the location of the coordinate point of the occurrence of flood. Learners are taught to map the location of the flood and find a solution. From the point of view of Natural Sciences learners are taught to find out the causes of the flood and find a solution. Learners are invited to analyze that is one of the piles of garbage in the gutter. Iskandar, et al (2015: 3) states from the point of view of social science learners are expected to be able to understand it is caused by human behavior itself.

Economic and social conditions become the bench-mark of the habit of littering. Social science when di-scussing the flood will be linked to the sociology of learning in society. From the standpoint of law and citizenship, learners are in the context of legal ob-edience. Learners are taught to be 
able to obey the law, ie do not throw garbage in place. Learning Indo-nesian is directed to teach students to be able to make an explanation of the phenomenon of flooding. Indonesian is incorporated into Math, Natural Sci-ence, Social Science and Civics, as a tool to explain flood phenomena.

Speaking has four skills that are the basis of communication skills. Siegler (2016: 129) believes that these skills are divided into two major skills, namely productive skills, namely speaking and writing and receptive skills, namely listening and reading.

The fifth grade elementary school students need to be prepared to face competition in the global world. Competition in the economic, social and tech-nological fields based on knowledge. Competitions need to be anticipated by training. In this paper, the results of the firsttier study will be presented. The first tier of research approaches the outer circle and an inner circle to find the instructions for use Indonesian learners fifth grade elementary school subjects were students and student Elementary School.

\section{RESERACH METHOD}

This study consisted of two layers of research. The first layer is ethnographic study and the second layer is classroom action research in the classroom.

\section{RESULT AND DISCUSSION}

\section{Ethnographic First Layer Research}

In this study the first tier research is the purpose of this research is (1) analysis of mixed vocabulary in language memory, and (2) indication of the process of storation in language learning that tends to be forced. The objects of observation in this study are (1) the theme of the conversation and (2) the purpose of using a speech. Observation of the use of language in an environment where there is a phenomenon of language overlap, (2) Observation of written text in the environment where the language is used, (3) Observation of the use of oral texts in the environment where the phenomenon of language overlap occurs and (4) Field notes.

Electronic recording devices are not used because the response is too slow to record unique speeches. In five experiments electronic recording devices experienced three main obstacles, namely (1) constrained battery availability, (2) too resonant resonance and (3) the activation process was too slow and missed important speeches. To collect data, observations were made in two circles. The outer circle (outer circle) that the use of speech of students who use the uniform elementary school in Malang and circle in which (inner circle) that students who wear uniforms elementary school in circles Jl Veteran, Bogor, Jakarta and Surabaya and region Sumbersari. Observations are carried out periodically in a span of 2 weeks. Data collection time is carried out between 2:00 p.m. and 10 p.m. in the outer and inner circles.
Classroom Action Research Methods as Second Layer Research

Classroom action research method is a method of improvement of teaching and learning process that occurs in elementary school environment. This study consists of 2 cycles. The focus that occurs in the first cycle is to install the concept of (1) the concept of coordinate in elementary school, (2) linkage concept of coordinate area with flood trigger and (3) make correlation of concept of coordinate area with solution to overcome flood. After evaluation, the following cycles are: (1) understanding the concept of longitude students (2) Understanding learners of the concept of latitude (3) Interpreting the concept of longitude to latitude and (4) Inviting learners to understand the concept of longitude and latitude into concrete language.

\section{Results of First Layer}

Based on observations found three utterances that are divided into one utterance in the outer circle and two utterances in the inner circle.

\section{Outer Circle}

The second phenomenon was found that a person had difficulty expressing in Indonesian in requesting services. disik"

“Aku ingin... Opo sih karepku iki. Koyoke tak bayar

(I want to ... I will not paid here)

The scene location settings are (1) the game center in the network (online), (2) the time setting is at noon around $1 \mathrm{pm}$. The purpose of speech is to pay for the package fee.

\section{Inner circle}

\section{Second phenomenon}

The phenomenon of difficulty in choosing phrases was found to help 11-year-old children in a photocopy. They uses mixed phrases

$$
\begin{aligned}
& \text { "Ma dipotong ae" } \\
& \text { "Bagaimana bentuknya?" } \\
& \text { "Ditempel ae wes" } \\
& \text { ("Mom, cut it downae" } \\
& \text { "What is the shape?" } \\
& \text { " It is attached") }
\end{aligned}
$$

Based on the results of interviews with their parents, found the backgrounds of their family are: (1) employees, and (2) housewives. The second phenomenon was discovered that an 11-year-old child had difficulty expressing in Indonesian in requesting services.

\section{Third phenomenon}

Wright (2015: 5) give opinions $d$ itemukan third phenomenon is a child 8 years old merge phrases in Indonesian and English.

"I want to buy, Apple, di jus saja."

" Apples bend on juice. 
The setting of the place in the speech event is (1) the shopping center (2) the cashier to pay.

\section{Findings}

\section{Outer Circle}

1) Combination of three speech languages, namely Javanese, (b) English and (c) Indonesian.

2) The setting of the place of speech is the center of the game or online game.

3) The time setting is during the day, after going home from school at $3 \mathrm{pm}$.

4) The location is at the center of the game Jl. Galunggung.

\section{Inner Circle}

\section{First phenomenon}

1) A combination of two languages, Javanese and Indonesian.

2) In a hurry to go home, the day will rain.

\section{Second phenomenon}

1) A combination of Javanese and English

2) Function to ask for help.

\section{Interpretation of Findings}

Outer Circle

\section{First Speech}

The use of utterances in the first finding is that speakers speak more of language as a function. The first step can be described as follows.

Speech objects: online game play at rental.

The purpose of speech: Request services in the form of package purchases.

\section{Inner circle}

\section{Second speech}

Ellis (1985: 4) gave the opinion that the use of total $p$ utterances in the second findings are more speakers of view language as a function. The first step can be described as follows.

\section{Speech objects: copy of the book}

The purpose of speech: ask for help from a book

\section{Third speech}

Brown, et al (1983: 2) states that the use of total $p$ utterances in the third finding is of speakers view language as a function. The first step can be described as follows.

Speech objects: buying and selling juice.

The purpose of speech: Ask for help to make juice.

\section{Results of Second Layer, Class Action Research}

\section{Simplifying Thematic Concepts of Language in Everyday Life}

Baeten, et al (2013: 484) states The viewer who grew up in an orphanage. Students whose condition is orphaned grew up in an orphanage as a worker abroad. The distance from the orphanage to his school was two miles, he took thirty minutes. From the point of view from home to school, there is a learner who lives on the edge of the river. Students are due to economic limitations in the morning after dawn must look for Fish in the river. At six-thirty in the morning, the learner takes the typical market for food to several stores. From the background of the parent's profession there is a protégé whose father works as a city transport driver. Mother of the learners work as a laundry worker in one laundry service. The child every morning also helps dry clothes, while one of his colleagues tells his brother works as a public bus. Therefore the simplification of language is done by transferring the language of learning, from the language of the language to the concrete every day. The concept of coordinates is linked to everyday life.

\section{Thematic Learning Linkage with Cross Curriculum Study}

Bai, et al (2014: 355) the learner who grew up in orphanage. Students whose condition is orphaned grew up in an orphanage as a worker abroad. The distance from the orphanage to his school was two miles, he took thirty minutes. From the point of view from home to school, there is a learner who lives on the edge of the river. Students are due to economic limitations in the morning after dawn must look for Fish in the river. At six-thirty in the morning, the learner takes the typical market for food to several stores. From the background of the parent's profession there is a protégé whose father works as a city transport driver. The mother of the students worked as a cu ci worker in one of the laundry services. The child every morning also dry clothes, while one of his colleague s tells his brother works in public bus.

\section{Design of Thematic-Based Theological Studies Cross- Curriculum}

Cerasoli, et al (2014: 980) said seen from the perspective of science The Curriculum 2013 textbook has been designed in accordance with the psychology of child development. Textbooks need to be translated because learners have a background heterogeneity. This textbooks are simple in accor-dance with the background understanding of learners. Given learning process needs to be improved. The solution given is the problem of the problem during the learning process.

\section{CONCLUSSION}

The three phenomena above are found in the outer circumference and inner circumference. Of the three phenomena above, 2 clues were found. The first clue (1) the use of language is more intended as a function, and (2) the language user includes more goals in various sentences.

\section{Suggestion}

It takes the development of Indonesian supplement materials to learners in elementary schools which has the following criteria: (1) educate using appropriate language setting place and time, and (2) training of language use in various tenses. Indonesian has two main subjects: literature and language. The author chooses material in the literary field because it can be given messages implicitly. Material selection is more 
focused on short stories with short story arguments having a simple plot to be assumed to be easier to understand.

\section{REFERENCES}

Agrawal, A. (2001). Common Property Institutions and Sustainable Baeten, M., Dochy, F., \& Struyven, K. (2013). The effects of different learning environments on students' motivation for learning and their achievement. British Journal of Educational Psychology, 83(3), 484501.

Bai, R., Hu, G., \& Gu, P. Y. (2014). The relationship between use of writing strategies and English proficiency in Singapore primary schools. The Asia-Pacific Education Researcher, 23(3), 355-365.

Brown, G., \&Yule, G. 1983. Discourse Analysis (Cambridge Textbooks in Linguistics). (1st ed.). Cambridge, United Kingdom: Cambridge University Press.
Cerasoli, C. P., Nicklin, J. M., \& Ford, M. T. (2014). Intrinsic motivation and extrinsic incentives jointly predict performance: A 40-year metaanalysis. Psychological Bulletin, 140(4), 980.

Cheng, R. W. Y., \& Lam, S. F. (2013). The interaction between social goals and self-construal on achievement motivation. Contemporary Educational Psychology, 38(2), 136-148.

Ellis, Rod. 1985. Understanding Second Language Acquisition. Oxford: Oxford University Press.

Iskandar, Y. R., Novianti, L. E., \& Siswanto, S. Y. (2015). The Role of Achievement Motivation Training Model-Based on E-Learning to Clarify Future Education Orientation of Adolescent in Jatinangor, Indonesia. GSTF Journal on Education (JEd), 2(2).

Siegler, R. S. (2016). Continuity and change in the field of cognitive development and in the perspectives of one cognitive developmentalist. Child Development Perspectives, 10(2), 128-133.

Wright, W. E. (2015). Foundations for teaching English language learners: Research, theory, policy, and practice. Caslon Incorporated 